\begin{tabular}{|l|l|}
\hline $\begin{array}{l}\text { 2. To: (Receiving Organization) } \\
\text { DISTRIBUTION }\end{array}$ & $\begin{array}{l}\text { 3. From: (Originating Organization) } \\
\text { INTERIM STABILIZATION }\end{array}$ \\
\hline $\begin{array}{l}\text { 5. Proj./Prog./Dept./Div.: } \\
\text { INTERIM STABILIZATION }\end{array}$ & $\begin{array}{l}\text { 6. Design Authority/Design Agent/Cog. Engr.: } \\
\text { W. F. ZUROFF }\end{array}$ \\
\hline $\begin{array}{l}\text { 8. Originator Remarks: } \\
\text { ATTACH IS A GUIDANCE DOCUMENT FOR SETTING UP THE FLOW COMPUTER ON } \\
\text { THE PUMPING INSTRUMENTATION AND CONTROL (PIC) SKIDS. THE FLOW } \\
\text { COMPUTER MONITORS THE RECIRCULATION FLOW ON THE JET PUMP. }\end{array}$
\end{tabular}

\begin{tabular}{|c|c|c|c|}
\hline \multicolumn{4}{|c|}{$\begin{array}{l}\text { 4. Related EDT No.: } \\
\text { N/A }\end{array}$} \\
\hline \multicolumn{4}{|c|}{$\begin{array}{l}\text { 7. Purchase Order No.: } \\
\text { N/A }\end{array}$} \\
\hline \multicolumn{4}{|c|}{ 9. Equip./Component No.: } \\
\hline \multicolumn{4}{|c|}{ 10. System/Bldg./Facility: } \\
\hline \multicolumn{4}{|c|}{$\begin{array}{l}\text { 12. Major Assm. Dwg. No.: } \\
\text { N/A }\end{array}$} \\
\hline \multicolumn{4}{|c|}{$\begin{array}{l}\text { 13. Permit/Permit Application No.: } \\
\text { N/A }\end{array}$} \\
\hline \multicolumn{4}{|c|}{ 14. Required Response Date: } \\
\hline (F) & (G) & (H) & (1) \\
\hline $\begin{array}{l}\text { Approval } \\
\text { Desig- } \\
\text { nator }\end{array}$ & $\begin{array}{c}\text { Reason } \\
\text { for Trans- } \\
\text { mittal }\end{array}$ & $\begin{array}{c}\text { Origi- } \\
\text { nator } \\
\text { Dispo- } \\
\text { stion }\end{array}$ & $\begin{array}{l}\text { Receiv- } \\
\text { er } \\
\text { Dispo- } \\
\text { sition } \\
\end{array}$ \\
\hline $\mathrm{N} / \mathrm{A}$ & 1 & 1 & 1 \\
\hline & & & \\
\hline & & & \\
\hline & & & \\
\hline & & & \\
\hline & & & \\
\hline & & & \\
\hline
\end{tabular}

\section{A. Design Baseline Document? $O$ Yes $O$ No}

KEY

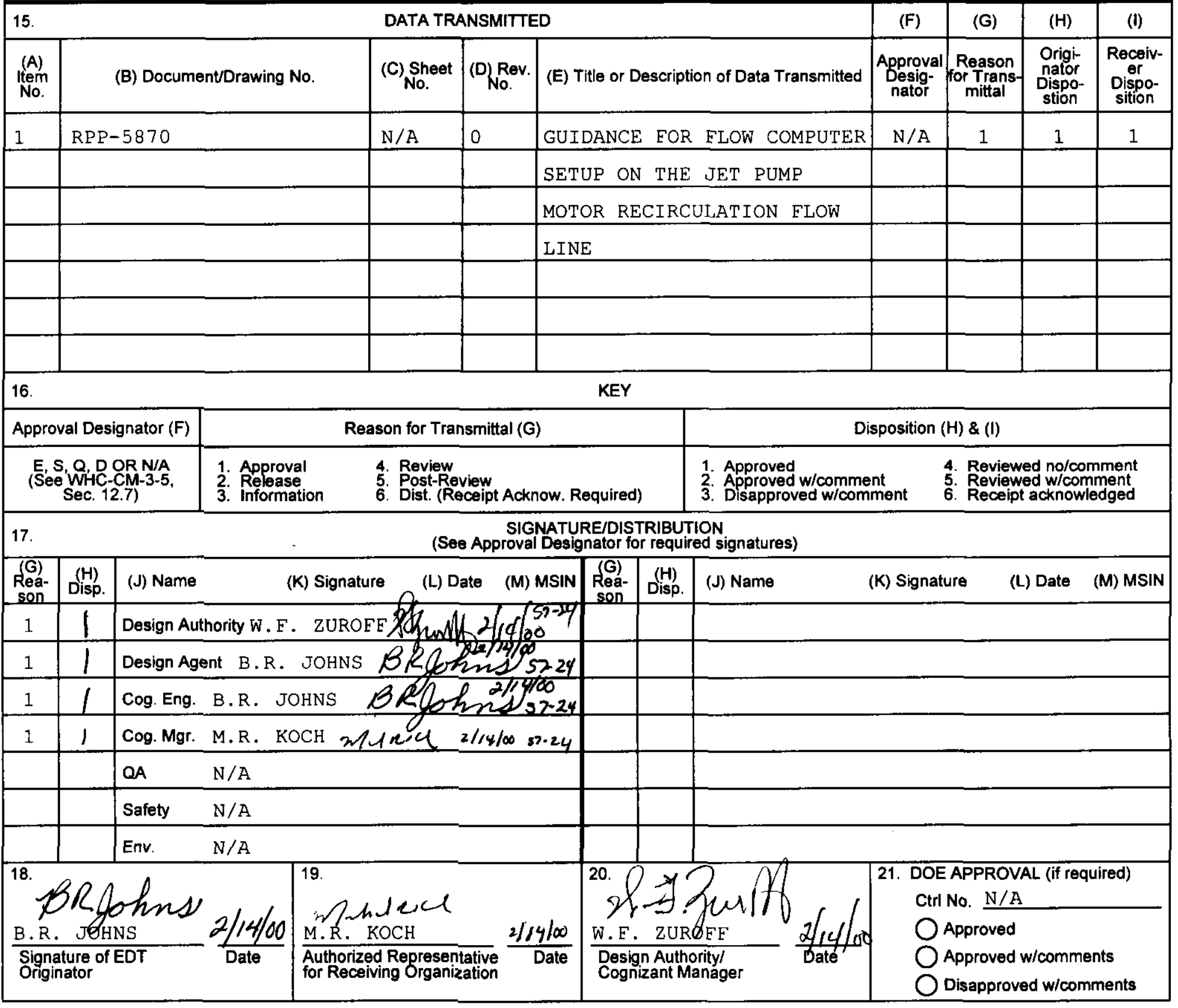

17.

BD-7400-172-2 (10/97)

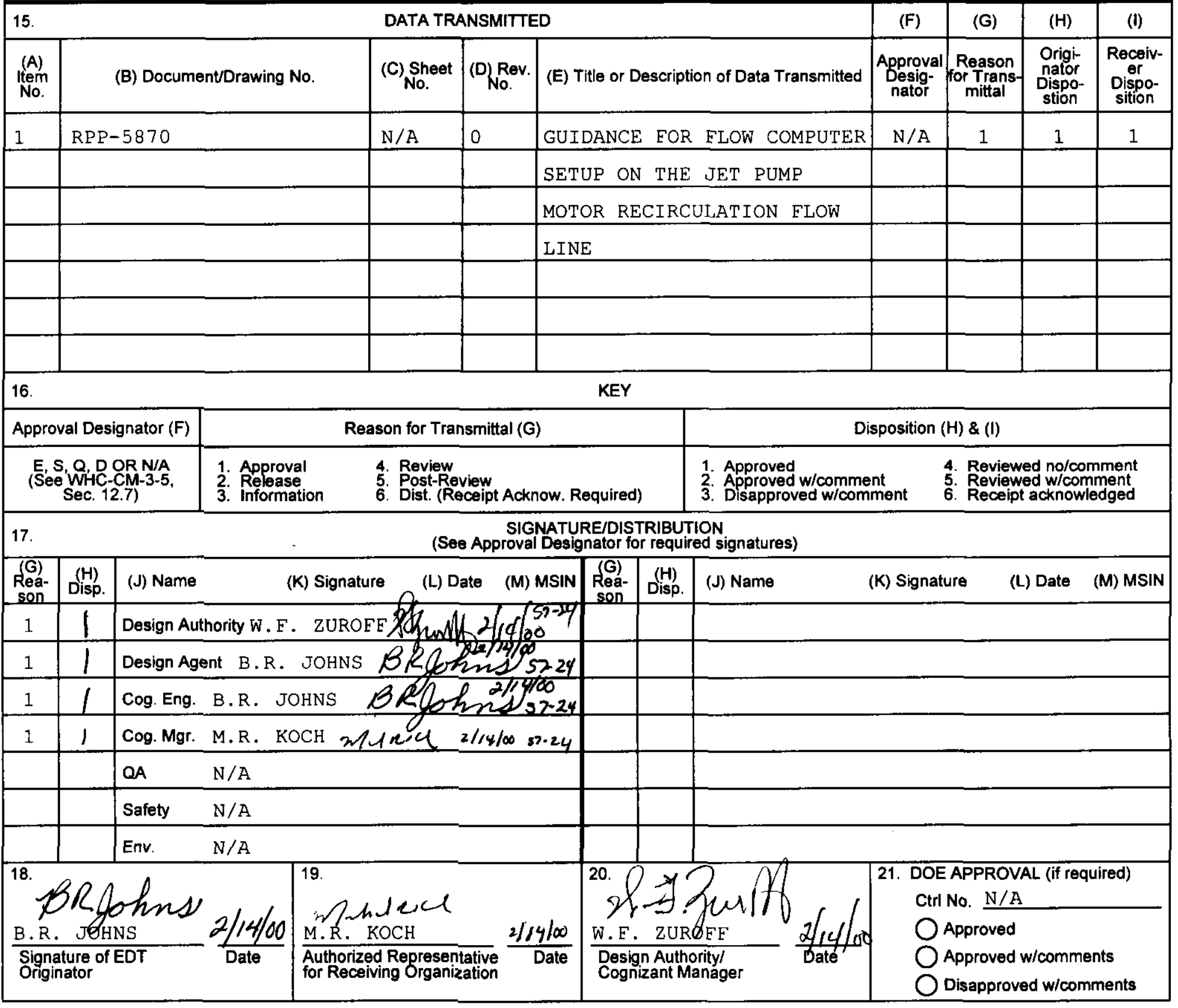

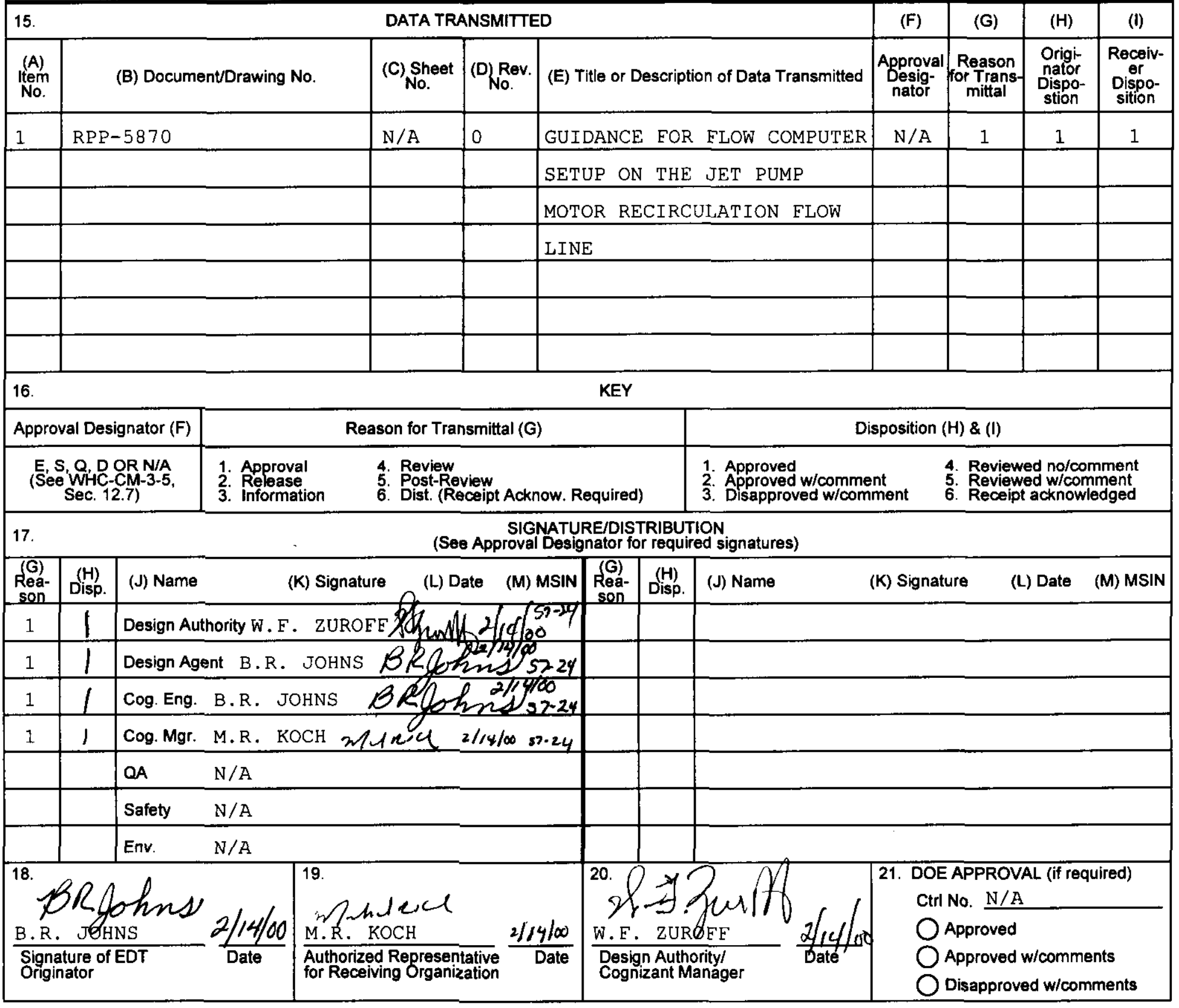
BD. $7400-172-1$ 


\title{
GUIDANCE FOR FLOW COMPUTER SETUP ON THE JET PUMP MOTOR RECIRCULATION FLOW LINE
}

M.R. KOCH

CH2MHILL HANEORD GROUP, INC

Richland, WA 99352

U.S. Department of Energy Contract DE-AC06-99RL14047

\author{
EDT/ECN: 624875 UC: \\ Cost Center: 74D00 Charge Code: 103361 \\ B\&R Code: EW3120071 Total Pages: 8
}

Key Words: CONTROLOTRON, ELOW COMPUTER, RECIRCULATION FLOW

\begin{abstract}
:
This document provides guidance for setting up and operating the flow computer on the PIC skids. The flow computer monitors the flow for the jet pump recirculation line.

*Controlotron is a registered trademark of Controlotron Corporation.
\end{abstract}

TRADEMARK DISCLAIMER. Reference herein to any specific commercial product, process, or service by trade name, trademark, manufacturer, or otherwise, does not necessarily constitute or imply its endorsement, recommendation, or favoring by the United States Government or any agency thereof or its contractors or subcontractors.

Printed in the United States of America. To obtain copies of this document, contact: Document Control Services, P.O. Box 950, Mailstop H6-08, Richland WA 99352, Phone (509) 372-2420; Fax (509) 376-4989.

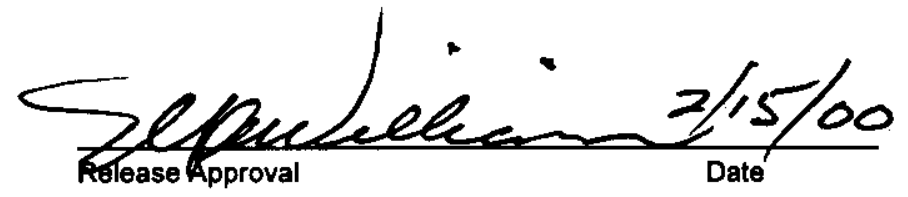

Approved For Public Release 


\section{GUIDANCE FOR FLOW COMPUTER SETUP ON THE JET PUMP MOTOR RECIRCULATION FLOW LINE}

\section{INTRODUCTION}

This document provides guidance for the programming, transducer mounting and startup of the flow computer to monitor the recirculation flow on the salt well jet pump. Monitoring of the recirculation flow is for verification that the pump motor has sufficient liquid for cooling the bearings. A portion of the pump's liquid discharge is routed through the pump motor bearing housing to remove heat generated when the motor is running. The routing path is through a half-inch stainless steel tube. Two ultrasonic transducers are mounted to this stainless steel tubing. Coaxial cables run from the two transducers back to the flow computer. The flow computer uses the signal from the transducers to determine the flow. An alarm function on the flow computer activates should the flow drop below a preset level when the pump is running.

\section{SCOPE}

This guidance only covers the Controlotron 1010 model flow computer and related transducers and mounting hardware. There are three sections to this guidance. Section 1 covers the flow computer initial program setup. Section 2 provides instructions for mounting the two ultrasonic transducers to the stainless steel tubing. Section 3 covers the final setup and operation for flowing monitoring. The field manual for the flow computer is referenced for more detailed information. The data table in the appendix is a summary of the flow computer programming actions that are required.

\section{GUIDANCE}

\section{SECTION 1: Flow Computer Setup}

Chapter 1 of the flow computer field manual provides general instructions for use of the flow computer keypad and menus. It is assumed that the personnel setting up and programming the flow computer have read and are able to navigate through the flow computer menu sets.

Flow Computer programming (initial):

- Go to the "Meter Facilities" menu to set the preferred units to "English", date and time, etc as per the table in the appendix. 
- "Clamp on" type needs to be selected in the "Meter Type" menu as shown in the table.

- Go to the following menus and set the parameters as indicated in the table in the appendix.

$>$ Channel Setup

$>$ Pipe Data

$>$ Application Data

$>$ Flow/Total Units

$>$ Data Span/Set/Cal

$>$ Stripchart

$>$ Datalogger Setup

$>$ I/O Data Control

\section{SECTION 2: Transducer Installation}

- Go to the "Pick/Install" menu. The flow computer will generate a recommended transducer type and mounting method. Record this information so it will be available during transducer mounting. NOTE: If the flow computers recommended transducer type and mounting method are not used, then the selections actually used must be entered into this menu before proceeding with the mounting. Engineering will assist in determining should a change to the flow computer recommendations be made.

- Follow the manufacturer's recommendations for mounting that are contained in chapter 3 of the field manual, in particular sections 3.1 and 3.4.

- The following are key points to be observed for transducer mounting.

$>$ Mount the transducers on the sides of the pipe, NOT the top and bottom.

$>$ Mount the transducers on the BOTTOM portion of the recirculation tube loop. (This is to prevent an empty pipe during no flow conditions.)

$>$ Follow the vendor's recommendations for placing coupling compound on the transducers.

$>$ Reference the skid drawing for shortening the track as needed to fit the tubing run.

- Connect the two coaxial cables to the transducers and to the flow computer. Be sure to that the "Upstream" transducer is at the beginning of the flow direction.

- $\quad$ Return to the "Pick/Install" menu and select "YES" for the "Install Complete?" section. The flow computer will now perform its checks to optimize the installation. NOTE: If a "Direct Mode" method was used for the transducer installation, then the Empty Pipe Set and Zero Flow Adjust routines must be performed. See sections 2.4.9 and 2.4.10 in the field manual for these routines.

- When the flow computer returns a "sonic velocity", then the settings are completed and flow monitoring is ready. 


\section{SECTION 3: Final Steps}

- Go to the "Diagnostic Data" menu and under the Test Facilities section select "Graph". Reference section 2.11.6 in the field manual for assistance. Check for optimal setting of the system on the graph displayed on the screen.

- Return to the flow display. When there is a flow in the recirculation line, a flow reading and a graph of the flow should appear on the screen.

- The "Operational Adjust" menu can be used to make adjustments as necessary for damping control.

- When the pump is placed in the pump pit and waste is circulating through the pump recirculation line, go back to the "Pick/Install" menu and repeat the "Install Complete?" routine. This will optimize for the waste material.

- When the pump is placed in the pump pit and waste is circulating through the pump recirculation line, some adjustments may be required due to the material of the waste. These adjustments would be in the "Applications Data" menu. The "liquid class" could be changed to compensate for the waste material. Could use "sea water" or possible an organic substance selection such as "kerosene" to help improve the readings. NOTE: Any change in the settings of the "Application Data" menu will require going back to the "Pick/Install" menu and repeating the "Install Complete?" routine. 


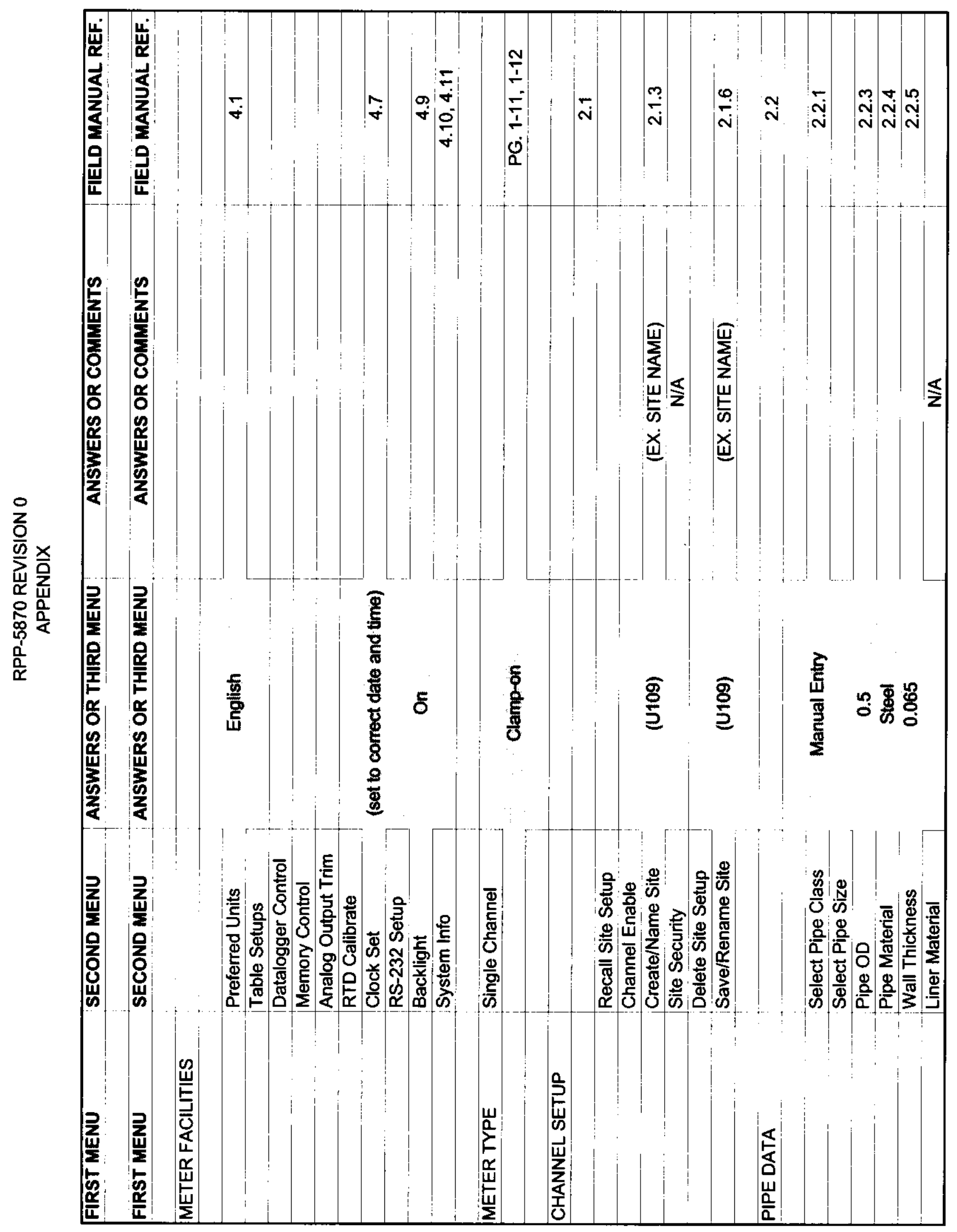

ปั 


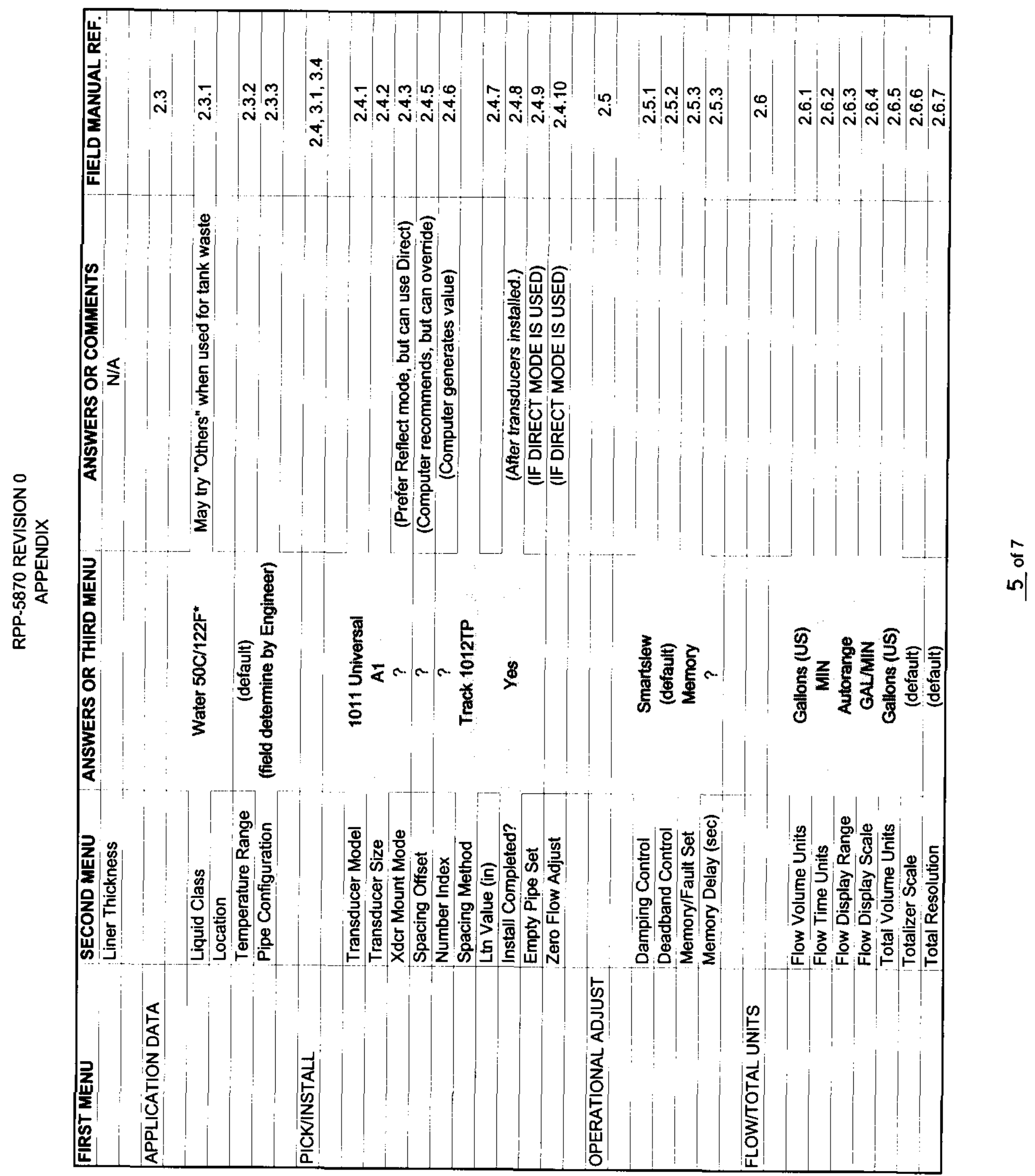




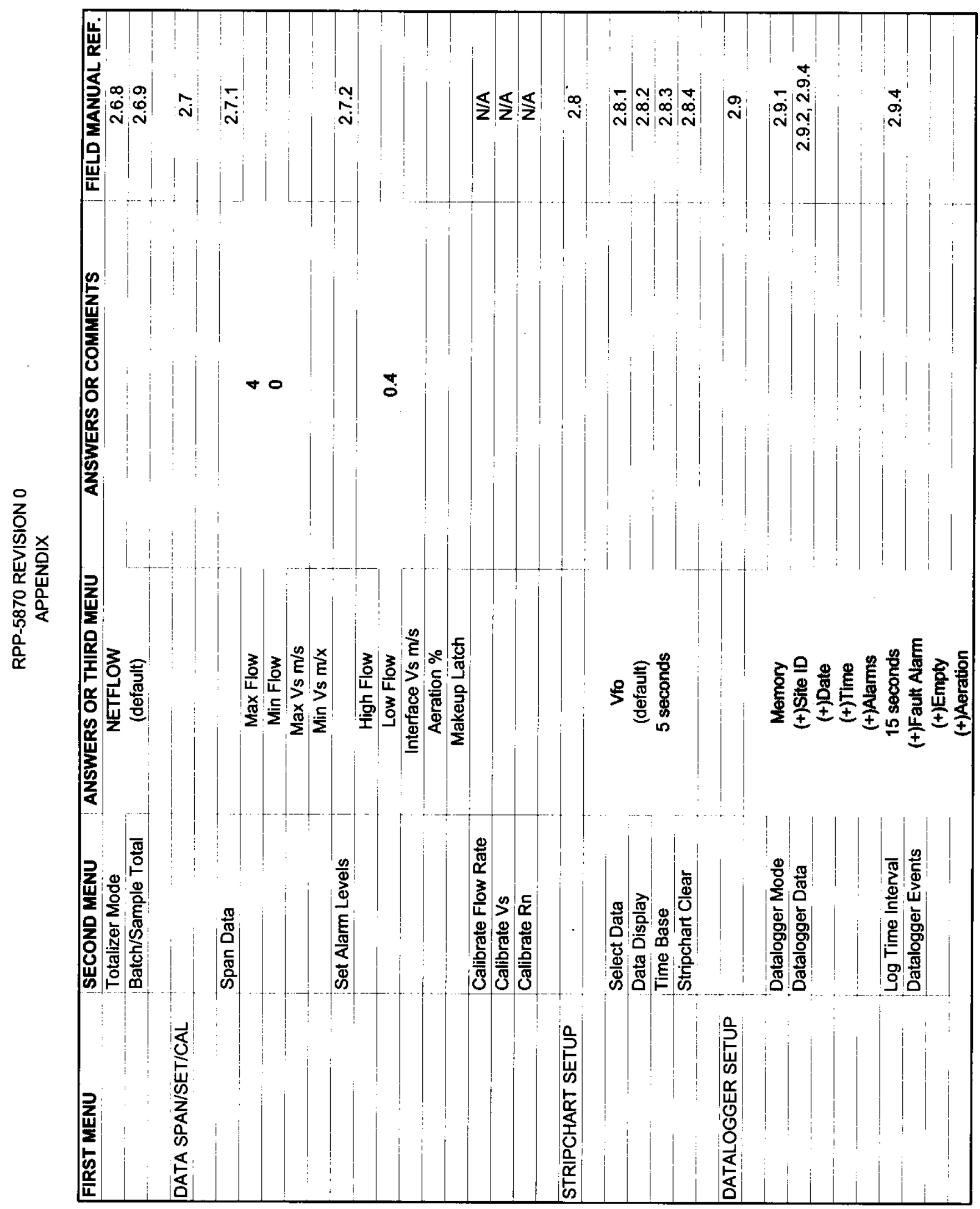




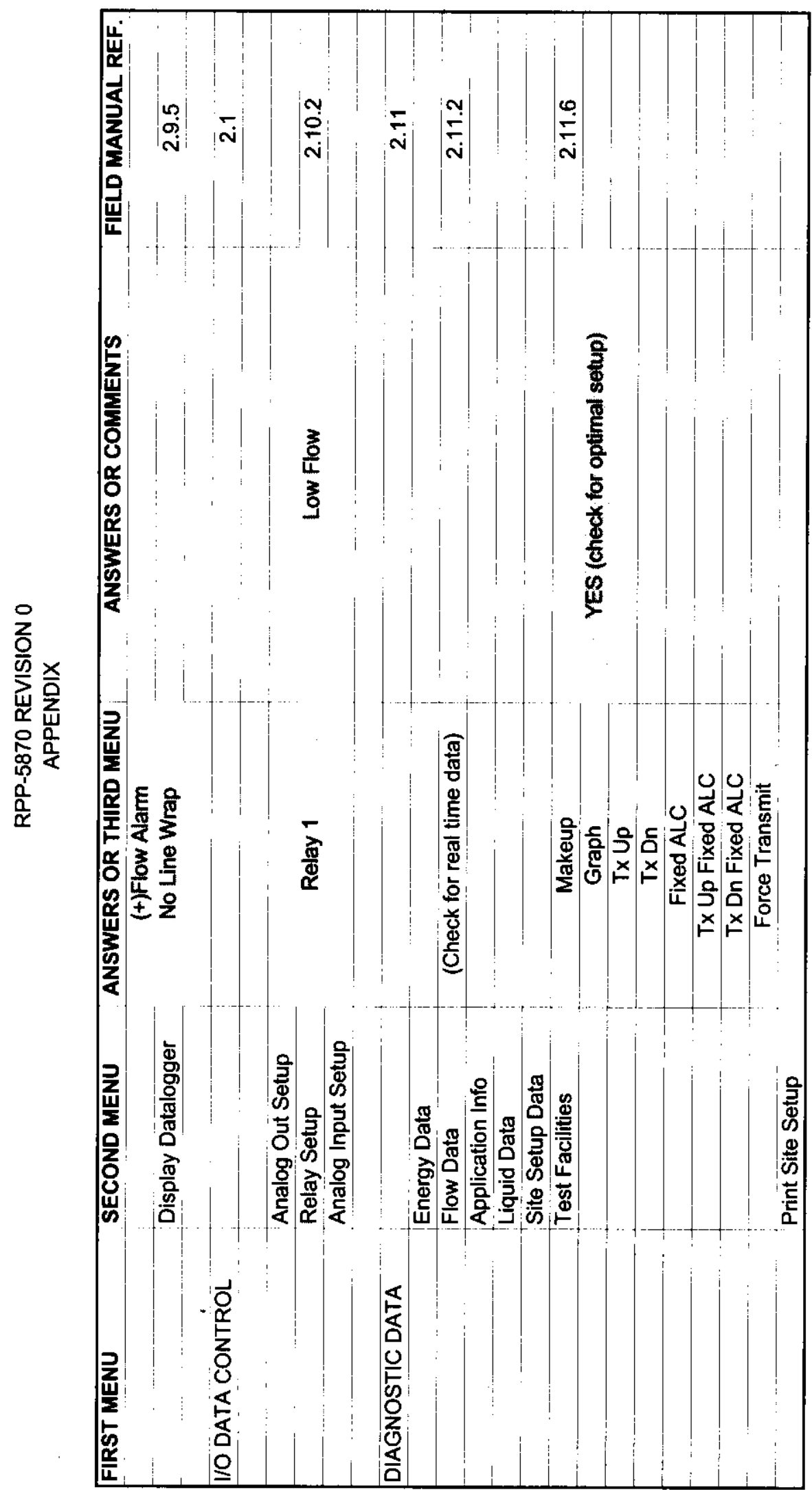

No 